\title{
BIOMASS AND NUTRIENTS REMOVAL IN PURE AND MIXED POPULATIONS OF Pinus sp. IN SOUTHWEST BAHIA - BRAZIL
}

\author{
Vanessa de Souza Gomes ${ }^{1}$, Patrícia Anjos Bittencourt Barreto-Garcia ${ }^{2 *}$, Adalberto Brito de Novaes ${ }^{3}$, Rafael \\ Nogueira Scoriza ${ }^{2}$, Mariana dos Santos Nascimento ${ }^{1}$, Monalisa Fagundes Oliveira ${ }^{1}$ \\ ${ }^{1}$ State University of Southwest Bahia, Vitória da Conquista, Bahia, Brazil - vanessadesouzagomes@ hotmail.com; rafaelscoriza@gmail.com; \\ nascimentoms30@gmail.com; monalisaffagundes@gmail.com \\ ${ }^{2 *}$ State University of Southwest Bahia, Department of Soil and Agricultural Engineering, Vitória da Conquista, Bahia, Brazil - \\ patriciabarreto@uesb.edu.br \\ ${ }^{3}$ State University of Southwest Bahia, Department of Zootechny and Phitotechny, Vitória da Conquista, Bahia, Brazil - \\ adallberto.brito@globo.com
}

Received for publication: 15/07/2018 - Accepted for publication: 01/10/2018

\begin{abstract}
Resumo
Biomassa e remoção de nutrientes em povoamentos puro e misto de Pinus sp. no Sudoeste da Bahia, Brasil. A magnitude da exportação de nutrientes com a colheita florestal depende do manejo de resíduos adotado e, sobretudo, da distribuição de biomassa e nutrientes das árvores, que é condicionada pelo potencial genético e composição de espécies do povoamento florestal. Este trabalho teve como objetivo quantificar a biomassa e os nutrientes das árvores e avaliar o efeito do manejo dos resíduos de colheita na remoção de nutrientes de plantios puro e misto de Pinus sp.. As áreas de estudo estão localizadas na região Sudoeste da Bahia. Assim sendo, foram selecionadas e abatidas 20 árvores por espécie nas duas condições de plantio. A quantificação da biomassa foi realizada pelo método destrutivo, retirando-se amostras dos componentes arbóreos que foram analisadas para determinação dos teores de $\mathrm{N}, \mathrm{P}, \mathrm{K}, \mathrm{Ca}$ e $\mathrm{Mg}$. A biomassa total foi de $75 \mathrm{Mg} \mathrm{ha}^{-1}$ para o plantio puro e de $81 \mathrm{Mg} \mathrm{ha}^{-1}$ para o plantio misto, tendo lenho e casca como compartimentos mais representativos. A retirada do lenho com casca ocasionou demasiada remoção de nutrientes, chegando a mais $50 \%$ do total contido na biomassa. O plantio misto mostrou-se mais propenso a exportação de P, K e Mg. Para ambos os plantios, $64 \%$ de N, P, K, Ca e Mg estão em outros componentes da parte aérea da árvore e não no lenho. No entanto, os elementos que representam maior risco para a manutenção da produtividade são $\mathrm{Ca}$ e $\mathrm{Mg}$.

Palavras-chave: Manejo de resíduos; Acúmulo de nutrientes; Colheita florestal.
\end{abstract}

\begin{abstract}
The magnitude of export of nutrients with forest harvest depends on the adopted waste management and, above all, on the distribution of biomass and nutrients in the trees, which is conditioned by the genetic potential and the species composition of forest stand. The objective of this study was to quantify the biomass and nutrients of the trees and evaluate the effect of the management of harvest residues on the removal of nutrients from pure and mixed plantations of Pinus sp.. The study areas are located in the Southwest region of Bahia State, Brazil. Twenty trees per species were selected and felled under both planting conditions. The biomass quantification was performed by the destructive method. Samples of the tree components were analyzed for N, P, K, Ca and $\mathrm{Mg}$ contents. The total biomass was $75 \mathrm{Mg} \mathrm{ha}^{-1}$ for pure planting, and $81 \mathrm{Mg} \mathrm{ha}^{-1}$ for mixed planting, with wood and bark as the most representative compartments. Removal of the wood with bark led to too much nutrient removal, reaching a further $50 \%$ of the total contained in the biomass. Mixed planting has been shown more prone to export P, K and Mg. For both plantations, $64 \%$ of the $\mathrm{N}, \mathrm{P}, \mathrm{K}, \mathrm{Ca}$ and $\mathrm{Mg}$ are in other components of the aerial part of the tree, and not in the wood. The elements that represent the highest risk for maintaining productivity are $\mathrm{Ca}$ and $\mathrm{Mg}$.
\end{abstract}

Keywords: Waste management; Nutrients accumulation; Forest harvest.

\section{INTRODUCTION}

Brazilian forestry sector has become recently one of the most relevant in the global scenario in economic terms, with 7.8 million hectares of planted forests. Species of the genus Pinus are among the most used in the country, occupying 1.6 million hectares (IBÁ, 2017). Much of this representativeness is linked to the genus' rusticity and tolerance, making possible its adaptation to low fertility soils and wide use of wood. In turn, the wood is used for the extraction of cellulose, civil construction, furniture, plywood, agglomerates, plates, and resins (EMBRAPA, 2014).

Rapidly growing forest species, such as those of the genus Pinus, show intense absorption of nutrients from the soil and, as a consequence, accumulate large amounts of biomass. For these reasons, the total or large-

FLORESTA, Curitiba, PR, v. 49, n. 3, p. 571 - 578, jul/set 2019.

Gomes, V. S. et.al.

ISSN eletrônico 1982-4688 
scale removal of this biomass at the time of thinning or harvest may negatively impact the site, reducing its productive capacity over time (SIXEL et al., 2015).

In this context, the adoption of conservationist management of crop residues in forest plantations may represent a reduction in costs, especially with supplemental mineral fertilization, which plays an important role in the reduction of nutrient exports, sustainability of production, and maintenance of site productivity (TUTUA et al., 2008). Such management allows tree components, such as top, leaves, branches, branches and barks to be left on the ground (PAES et al., 2013) and reused in the natural process of nutrient cycling.

Although there are proven benefits of conservation management, forest harvesting with only leaf and branch maintenance (removal of stem with bark) is still widely adopted in some regions of the country, especially in small and medium-sized rural properties, where forest activities lack technification. This latter management promotes greater export of nutrients from the site, however it requires greater attention and costs with the correction of soil fertility (BELLOTE et al., 2008).

In addition to the type of management adopted, the extraction of nutrients depends on other factors, such as species composition, genetic potential, and age of forest stands, for example. In this condition, studies on the distribution of biomass and nutrients in different components of the trees can: i. allow an adequate evaluation of the impacts that the removal of timber resource can cause in the ecosystem; ii. help in understanding the nutritional dynamics; and iii. reduce the excessive use of fertilizers, optimizing the production of Pinus.

In spite of the fact that several studies have been carried out on biomass and nutrient exports in homogenous stands of Pinus (VIERA et al., 2011; SIXEL et al., 2015; CORRÊA; BELLOTE, 2011; SCHUMACHER et al., 2013; LIMA et al., 2016), no records have been found in up-to-date literature on studies of mixed plantings of species of the same genus. Therefore, the objective of this study was to quantify the biomass and nutrients of the aerial part of trees and to evaluate the effect of harvest residues management on the removal of nutrients from pure and mixed plantations of Pinus sp.. It is assumed, hence, that the nutritional dynamics of these stands differ according to the composition of the species and the adopted management.

\section{MATERIAL AND METHODS}

\section{Study area characterization}

The study was carried out in two forest stands: a pure one of Pinus caribaea var. hondurensis and a mixed composed of Pinus caribaea var. hondurensis and Pinus oocarpa. Both stands were 10 years old, spaced $3 \times 3 \mathrm{~m}$ and located in the experimental area of the State University of Southwest Bahia, campus of Vitória da Conquista (state of Bahia - Brazil), whose geographic coordinates are $14^{\circ} 53^{\prime}$ South latitude and $40^{\circ} 48^{\prime}$ West longitude.

The stands were implanted in a low secondary shrub area, where it was executed the cleaning with a tracktype tractor and, after that, harrowing. The planting (seminal) was done with fertilization located in the pit (200 g of simple superphosphate). Maintenance in the area was performed by means of periodic weeding between the lines up to 12 months after planting.

The local climate is tropical high-altitude $(\mathrm{Cwb})$, according to Köppen classification, with annual average temperature of $21^{\circ} \mathrm{C}$ and rainfall varying between 700 and $1100 \mathrm{~mm}$ annually, which is distributed in the months of November to March, with a dry period of four to five months. The topography is considered flat to slightly undulating, with altitude around $880 \mathrm{~m}$. The soil of the studied areas belongs to the class Dystrophic Yellow Latosol and presents chemical characteristics according to Table 1. For the chemical analyzes, the soil samples were collected at depth $0-20 \mathrm{~cm}$ in four plots of $15 \times 15 \mathrm{~m}$. From each plot, a sample composed of 20 simple samples was taken, totalizing four samples composed by the studied stands.

Tabela 1. Caracterização química de solo (profundidade 0-10 cm) sob plantios puro de Pinus caribaea e misto de Pinus caribaea e Pinus oocarpa.

Table 1. Soil chemical characterization (depth 0-10 cm) under pure plantings of Pinus caribaea and mixed of Pinus caribaea and Pinus oocarpa.

\begin{tabular}{|c|c|c|c|c|c|c|c|c|c|c|}
\hline Coverage & $\mathrm{pH}$ & $\mathrm{MO}$ & $\mathrm{P}$ & K & $\mathrm{Ca}$ & $\mathrm{Mg}$ & $\mathrm{H}+\mathrm{Al}$ & $\mathrm{Al}$ & $\mathrm{V}$ & $\mathrm{M}$ \\
\hline & & $\mathrm{g} \mathrm{dm}^{-3}$ & $\underset{3}{\mathrm{mg} \mathrm{dm}^{-}}$ & & 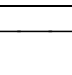 & $\mathrm{ol}_{\mathrm{c}} \mathrm{d}$ & & & & - \\
\hline Mixed Pinus & 5.1 & 20 & 1.0 & 0.23 & 1.0 & 0.9 & 3.8 & 0.3 & 36 & 12 \\
\hline Pinus caribaea & 4.7 & 18 & 1.0 & 0.14 & 1.0 & 1.0 & 4.8 & 0.8 & 27 & 31 \\
\hline
\end{tabular}




\section{Biomass and nutrients}

The trees sampling for the quantification of biomass was carried out from the measurement of the diameter at the breast height (DBH) of all the individuals. The DBH measurements of each species by population were grouped into three diametric classes with amplitude corresponding to $6.0 \mathrm{~cm}$, according to Table 2 . The selection of the sample trees occurred randomly and proportionally to the frequency of each diametric class. It was selected and felled 20 trees from the pure plantation and 40 from the mixed plantation (i. e., 20 trees of Pinus oocarpa and 20 trees of Pinus caribaea), being distributed in the three diameter classes (Table 2).

Tabela 2. Distribuição diamétrica dos plantios puro de Pinus caribaea e misto de Pinus caribaea e Pinus oocarpa. Table 2. Diametric distribution of pure plantings Pinus caribaea and mixed Pinus caribaea and Pinus oocarpa.

\begin{tabular}{|c|c|c|}
\hline Classes of DBH $(\mathrm{cm})$ & Class Center $(\mathrm{cm})$ & fi \\
\hline & \multicolumn{2}{|l|}{$\mathrm{PCP}^{(1)}$} \\
\hline $7.00-12.99$ & 10.0 & 167 \\
\hline $13.00-18.99$ & 16.0 & 593 \\
\hline \multirow[t]{2}{*}{$19.00-25.00$} & 22.0 & 89 \\
\hline & \multicolumn{2}{|c|}{ PCM } \\
\hline $8.00-13.99$ & 11.0 & 32 \\
\hline $14.00-19.99$ & 17.0 & 200 \\
\hline \multirow[t]{2}{*}{$20.00-26.00$} & 23.0 & 182 \\
\hline & \multicolumn{2}{|c|}{ POM } \\
\hline $7.00-12.99$ & 10.0 & 55 \\
\hline $13.00-18.99$ & 16.0 & 209 \\
\hline $19.00-25.00$ & 22.0 & 159 \\
\hline
\end{tabular}

${ }^{(1)} \mathrm{PCP}=$ Pinus caribaea in pure planting; $\mathrm{PCM}=$ Pinus caribaea in mixed planting; $\mathrm{POM}=$ Pinus oocarpa in mixed planting; $\mathrm{DBH}=$ diameter at breast height at $1.3 \mathrm{~m}$ from ground level; $f \mathrm{i}=$ frequency of tree individuals with $\mathrm{DBH} \geq 5 \mathrm{~cm}$ per hectare.

Each sample-tree was fractionated in the components of the needles, branches, bark and stem, which had their fresh mass determined in the field, using a mechanical scale with a capacity of $150 \mathrm{~kg}$ and a precision of 50 g. After weighing, samples with about $300 \mathrm{~g}$ of each component were taken. In the case of stem and bark, three samples per tree were collected in three positions of the stem (base, intermediate and upper extremity). Samples of each component were oven dried $\left(65^{\circ} \mathrm{C}\right)$ and weighed $(0.01 \mathrm{~g}$ precision). Thus, based on the values of humid and dry mass of each sample and of the humid mass determined in the field, it was estimated the total dry biomass $(\mathrm{kg})$ of the aerial part and of each component. The values obtained were projected for hectare.

To evaluate the content of macronutrients ( $\mathrm{N}, \mathrm{P}, \mathrm{K}, \mathrm{Ca}$ and $\mathrm{Mg}$ ), two representative trees of each diameter class were selected, totaling six trees per species. This number of trees was defined based on studies found in literature, which adopted a sample number between one and three trees per class of DBH for nutrient analysis (SCHUMACHER; CALDEIRA, 2001; MADEIRA et al., 2009; SCHUMACHER et al., 2013; CALDEIRA et al., 2014). The dried samples of the components of the selected trees were ground in a Willey-type mill. Subsequently, N contents were determined by the Kjeldahl method (by sulfur digestion), P was determined by spectrophotometry, $\mathrm{K}$ by flame photometry, $\mathrm{Ca}$ and $\mathrm{Mg}$ by atomic absorption spectrometry, following the methodologies described by Tedesco et al. (1995).

The stock of macronutrients of each component of the biomass $\left(\mathrm{kg}^{\mathrm{tree}} \mathrm{e}^{-1}\right)$ was obtained from the multiplication of their concentrations by the respective values of dry biomass. In turn, the total stock of macronutrients of each tree was obtained by summing the stocks of their compartments. Additionally, the amount stored per unit area $\left(\mathrm{Mg} \mathrm{ha}^{-1}\right)$ was obtained by the product between the mean nutrient stock of each biomass component and number of trees per hectare. In the case of mixed planting, considering that half of its area was occupied by Pinus caribaea and the other half by Pinus oocarpa, the biomass of each species was extrapolated to half a hectare $(0.5 \mathrm{ha})$. Consequently, these results were added in order to find the corresponding value to one hectare.

\section{Removal of nutrients}

The estimation of nutrient removal with biomass harvest was performed by means of simulation of three conditions of waste management: 1 - removal of the entire tree, without maintenance of residues; 2 - maintenance of needles and branches on the site, removal of the stem with bark; and 3 - maintenance of all residues (needles, branches and barks), removal of only the stem. So, the percentage of removal of each nutrient was calculated for each management and type of planting (pure and mixed).

FLORESTA, Curitiba, PR, v. 49, n. 3, p. 571 - 578, jul/set 2019.

Gomes, V. S. et.al.

ISSN eletrônico 1982-4688 


\section{Statistical procedures}

The data were analyzed for normality (Shapiro-Wilk) and homogeneity (Bartlett). The biomass results were compared by the Tukey test at $5 \%$ significance and the nutrient values were compared by the Wilcoxon test (to compare the treatments) and Kruscall-Wallis (to compare the species), both at $5 \%$.

\section{RESULTS}

\section{Biomass stocks and nutrient contents}

On the one hand, in the pure population of Pinus caribaea, the trees presented DBH ranging from 7.0 to $23.8 \mathrm{~cm}$. On the other hand, in the mixed population, the DBH ranged from 8.1 to $25.5 \mathrm{~cm}$ for Pinus caribaea and 7.5 to $25.0 \mathrm{~cm}$ for Pinus oocarpa. For both species, the biomass distribution in different compartments of trees showed greater participation of the stem, which represented more than $56 \%$ and less contribution of the needles, which constituted 5 to $7 \%$ of the total biomass (Table 3). The bark and branches had intermediate participation, representing 19.6 and $16.7 \%$, respectively. The total biomass per unit area was approximately $75 \mathrm{Mg} \mathrm{ha}^{-1}$ in the pure plantation and $81 \mathrm{Mg} \mathrm{ha}^{-1}$ in the mixed, which corresponds, on average, to 67.9 and $75.4 \mathrm{~kg} \mathrm{tree}^{-1}$, respectively (Table 3).

Tabela 3. Estoques de biomassa seca e participação de cada compartimento da parte aérea na composição da biomassa total de Pinus caribaea em plantio puro e Pinus caribaea e Pinus oocarpa em plantio misto

Table 3. Dry biomass stocks and share of each compartment of the aerial part in the composition of the total biomass of Pinus caribaea in pure plantation and Pinus caribaea and Pinus oocarpa in mixed planting.

\begin{tabular}{|c|c|c|c|c|c|c|}
\hline \multirow{2}{*}{$\begin{array}{l}\text { Component } \\
\text { of biomass }\end{array}$} & \multicolumn{2}{|c|}{$\mathrm{PCP}^{(1)}$} & \multicolumn{2}{|c|}{ PCM } & \multicolumn{2}{|c|}{ POM } \\
\hline & $\mathrm{kg}_{\text {tree }}{ }^{-1}$ & $\%$ & kg tree ${ }^{-1}$ & $\%$ & $\mathrm{~kg}$ tree $^{-1}$ & $\%$ \\
\hline Needles & 4.04 & 5.96 & 5.45 & 7.02 & 4.34 & 5.94 \\
\hline Branches & 11.20 & 16.50 & 11.80 & 15.20 & 13.47 & 18.42 \\
\hline Bark & 14.18 & 20.89 & 15.90 & 20.50 & 12.66 & 17.30 \\
\hline Stem & 38.45 & 56.65 & 44.45 & 57.28 & 42.66 & 58.34 \\
\hline Total & 67.88 & 100 & 77.59 & 100 & 73.13 & 100 \\
\hline
\end{tabular}

The concentrations of $\mathrm{N}, \mathrm{P}, \mathrm{K}, \mathrm{Ca}$ and $\mathrm{Mg}$ in the aerial biomass are shown in Table 4. For both plantings, the highest levels of nutrients were found in the needles. After this component, the distribution of the contents followed the order: branches> bark> stem.

When comparing the species of Pinus in the two planting conditions, it was verified that, in general, the concentrations of nutrients suffered small changes. The most striking differences were observed only for $\mathrm{P}$ (on the needles) and $\mathrm{Ca}$ (on the stem), which presented higher concentrations in $P$. caribaea in pure planting.

Tabela 4. Teores de nutrientes nos diferentes componentes de árvores de Pinus sp. em plantio puro e misto com 10 anos de idade.

Table 4. Nutrient contents in the different components of Pinus sp. in pure and mixed planting with 10 years of age.

\begin{tabular}{|c|c|c|c|c|c|c|c|}
\hline \multirow{2}{*}{ Component } & \multirow{2}{*}{ Species } & \multicolumn{6}{|c|}{ Macronutrients $\left(\mathrm{g} \mathrm{kg}^{-1}\right)$} \\
\hline & & $\mathrm{N}$ & $\mathrm{P}$ & $\mathrm{K}$ & $\mathrm{Ca}$ & $\mathrm{Mg}$ & \\
\hline \multirow{3}{*}{ Needles } & $\mathrm{PCP}^{(1)}$ & $10.31 \mathrm{a}$ & $0.51 \mathrm{a}$ & $4.77 \mathrm{ab}$ & $2.44 \mathrm{a}$ & 1.14 & a \\
\hline & PCM & $9.64 \mathrm{a}$ & $0.32 \mathrm{~b}$ & $3.68 \mathrm{~B}$ & $1.46 \mathrm{~b}$ & 0.87 & $\mathrm{a}$ \\
\hline & POM & $9.65 \mathrm{a}$ & $0.31 \mathrm{~b}$ & $5.63 \mathrm{a}$ & $1.53 \mathrm{~b}$ & 0.95 & $\mathrm{a}$ \\
\hline \multirow{3}{*}{ Branches } & PCP & $2.04 \mathrm{a}$ & $0.09 \mathrm{a}$ & $0.82 \mathrm{~B}$ & $1.64 \mathrm{a}$ & 0.34 & $\mathrm{a}$ \\
\hline & PCM & $1.67 \mathrm{ab}$ & $0.14 \mathrm{a}$ & $0.87 \mathrm{~B}$ & $1.29 \mathrm{a}$ & 0.36 & $\mathrm{a}$ \\
\hline & POM & $1.40 \mathrm{~b}$ & $0.13 \mathrm{a}$ & $1.32 \mathrm{~A}$ & $1.31 \mathrm{a}$ & 0.29 & a \\
\hline \multirow{3}{*}{ Bark } & PCP & $1.64 \mathrm{ab}$ & $0.05 \mathrm{~b}$ & $0.77 \mathrm{~A}$ & $0.66 \mathrm{a}$ & 0.14 & $\mathrm{a}$ \\
\hline & PCM & $1.93 \mathrm{a}$ & $0.07 \mathrm{a}$ & $0.47 \mathrm{~A}$ & $0.90 \mathrm{a}$ & 0.15 & $\mathrm{a}$ \\
\hline & POM & $1.58 \mathrm{~b}$ & $0.06 \mathrm{ab}$ & $1.07 \mathrm{~A}$ & $0.84 \mathrm{a}$ & 0.14 & $\mathrm{a}$ \\
\hline
\end{tabular}




\begin{tabular}{clllllllllll} 
& \multicolumn{1}{c}{ PCP } & 1.16 & $\mathrm{a}$ & 0.03 & $\mathrm{a}$ & 0.45 & $\mathrm{~B}$ & 0.69 & $\mathrm{a}$ & 0.22 & $\mathrm{a}$ \\
\multirow{3}{*}{ Stem } & PCM & 0.96 & $\mathrm{a}$ & 0.04 & $\mathrm{a}$ & 0.85 & $\mathrm{ab}$ & 0.48 & $\mathrm{~b}$ & 0.23 & $\mathrm{a}$ \\
& POM & 0.89 & $\mathrm{a}$ & 0.04 & $\mathrm{a}$ & 1.23 & $\mathrm{~A}$ & 0.47 & $\mathrm{~b}$ & 0.19 & $\mathrm{a}$ \\
\hline
\end{tabular}

(1) $\mathrm{PCP}=$ Pinus caribaea in pure planting; $\mathrm{PCM}=$ Pinus caribaea in mixed planting; POM = Pinus oocarpa in mixed planting; Equal letters in vertical, which compare the nutrient contents of each tree component among species, do not differ from each other, according to the KruscallWallis test at $5 \%$ significance.

The order of distribution of nutrient contents for most of the compartments of the two species of Pinus was $\mathrm{N}>\mathrm{K}>\mathrm{Ca}>\mathrm{Mg}>\mathrm{P}$. The only exception was the stem component of Pinus oocarpa, which presented higher content of $\mathrm{K}$ instead of $\mathrm{N}$.

\section{Removal of nutrients by biomass removal}

The estimation of the nutrient removal for the three conditions of waste management is presented in Table 5. It was possible to observe the occurrence of a nutrient export gradient, which varied according to the type of planting. For pure planting, regardless of the management adopted, the removal occurred in the order $\mathrm{N}>\mathrm{Ca}>\mathrm{K}>$ $\mathrm{Mg}>\mathrm{P}$, while in the mixed plantation the export order was $\mathrm{N}>\mathrm{K}>\mathrm{Ca}>\mathrm{Mg}>\mathrm{P}$ in managements 1 and 2, observing the inversion of $\mathrm{N}$ and $\mathrm{K}$ in management $3(\mathrm{~K}>\mathrm{N}>\mathrm{Ca}>\mathrm{Mg}>\mathrm{P})$.

Tabela 5. Remoção de nutrientes em função da retirada de biomassa e manejo dos resíduos em plantios puro ou misto de Pinus sp. com 10 anos de idade.

Table 5. Nutrients removal due to biomass removal and management of residues in pure or mixed plantations of Pinus sp. with 10 years of age.

\begin{tabular}{|c|c|c|c|c|c|c|c|c|c|c|}
\hline \multirow{3}{*}{$\begin{array}{c}\text { Waste } \\
\text { management }\end{array}$} & \multicolumn{10}{|c|}{ Nutrients } \\
\hline & \multicolumn{2}{|c|}{$\mathrm{N}$} & \multicolumn{2}{|c|}{$\mathrm{P}$} & \multicolumn{2}{|c|}{ K } & \multicolumn{2}{|c|}{$\mathrm{Ca}$} & \multicolumn{2}{|c|}{$\mathrm{Mg}$} \\
\hline & $\mathrm{kg} \mathrm{ha}^{-1}$ & $\%^{(1)}$ & $\mathrm{kg} \mathrm{ha}^{-1}$ & $\%$ & $\mathrm{~kg} \mathrm{ha}^{-1}$ & $\%$ & $\mathrm{~kg} \mathrm{ha}^{-1}$ & $\%$ & $\mathrm{~kg} \mathrm{ha}^{-1}$ & $\%$ \\
\hline & \multicolumn{10}{|c|}{ Pure planting } \\
\hline 1 & 141.8 & 100.0 & 5.1 & 100.0 & 60.5 & 100.0 & 72.59 & 100.0 & 21.34 & 100.0 \\
\hline 2 & 70.9 & 50.0 & 1.8 & 34.3 & 29.7 & 49.1 & 41.41 & 57.1 & 11.93 & 55.9 \\
\hline \multirow[t]{2}{*}{3} & 49.0 & 34.6 & 1.1 & 20.9 & 20.4 & 33.9 & 29.59 & 40.8 & 9.61 & 45.0 \\
\hline & \multicolumn{10}{|c|}{ Mixed planting } \\
\hline 1 & 148.5 & 100.0 & 6.5 & 100.0 & 95.6 & 100.0 & 62.88 & 100.0 & 21.27 & 100.0 \\
\hline 2 & 71.8 & 48.4 & 2.8 & 43.7 & 58.0 & 60.7 & 36.29 & 57.7 & 11.94 & 56.2 \\
\hline 3 & 43.4 & 29.2 & 1.8 & 28.5 & 45.8 & 47.9 & 22.62 & 36.0 & 9.78 & 46.0 \\
\hline
\end{tabular}

(1) $\%$ = percentage of nutrient removal according to the waste management adopted: 1 - removal of the entire tree, without maintenance of residues; 2 - maintenance of needles and branches on the site, removal of the stem with bark; and 3 - maintenance of all residues (needles, branches and barks), removal of only the stem.

For the nutrients $\mathrm{P}, \mathrm{K}$ and $\mathrm{Mg}$, there was greater export in the mixed plantation in relation to the pure one (Table 4). Nevertheless, for both plantations, the removal of all nutrients was reduced with the adoption of only wood removal and maintenance of other components in the field (management 3 ). This management avoided the removal of: $65 \% \mathrm{~N}, 79 \% \mathrm{P}, 69 \% \mathrm{~K}, 59 \% \mathrm{Ca}$ and $55 \% \mathrm{Mg}$ in pure planting and $71 \% \mathrm{~N}, 72 \% \mathrm{P}, 52 \% \mathrm{~K}, 64 \% \mathrm{Ca}$ and $54 \% \mathrm{Mg}$ in mixed planting. By admitting the removal of stem along with bark (management 2), this permanence of nutrients decreased to: $50 \% \mathrm{~N}, 66 \% \mathrm{P}, 51 \% \mathrm{~K}, 43 \% \mathrm{Ca}$ and $44 \% \mathrm{Mg}$ in pure planting and $52 \% \mathrm{~N}$, $56 \% \mathrm{P}, 39 \% \mathrm{~K}, 42 \% \mathrm{Ca}$ and $44 \% \mathrm{Mg}$ in mixed planting. By analyzing the nutrients together, it was observed that management 2 caused $53 \%$ of all $\mathrm{N}, \mathrm{P}, \mathrm{K}, \mathrm{Ca}$ and $\mathrm{Mg}$ stored in the tree biomass to be exported, while in management 3 this value was reduced to $36 \%$ (Table 4).

\section{DISCUSSION}

The biomass results in $\mathrm{Mg} \mathrm{ha}^{-1}$ observed in both plantations are lower than those found by Sette Júnior et al. (2006) for Pinus taeda with 12 years of age in Santa Catarina State - Brazil (148 Mg.ha-1 $)$, and Corrêa and Bellote (2011) for Pinus caribaea with 11 years of age in the state of São Paulo - Brazil (264 Mg.ha-1). The lower biomass observed in the present study may be related to the adaptation of the species to the studied region, which

FLORESTA, Curitiba, PR, v. 49, n. 3, p. 571 - 578, jul/set 2019.

Gomes, V. S. et.al.

ISSN eletrônico 1982-4688

DOI: $10.5380 /$ rf.v49 i3.60531 
presents low levels of rainfall and soil fertility (Table 1) or the absence of application of silvicultural practices in established planting, such as maintenance and thinning, for example.

Moreover, the biomass distribution pattern in the different compartments of the trees (stem> bark> branches> needles) (Table 3) is similar to that observed by Lima et al. (2016) and Corrêa and Bellote (2011) in stands of Pinus caribaea in the states of Bahia and São Paulo (Brazil), respectively. In contrast, Sixel et al. (2015), for plantings of Pinus taeda with 16 years of age, and Schumacher et al. (2013), for Pinus taeda with 27 years of age, verified biomass distribution in the sequence: stem> branches $>$ bark> needles. According to Pedrosa et al. (2013), the allocation of biomass in the different components of the trees can vary between species, within the same species or due to variations in environmental conditions.

Together, stem and bark made, on average, $77 \%$ of the above-ground tree biomass in pure and mixed plantations. This indicates that harvesting with stem removal without bark stripping would imply the export of a significant proportion of the total biomass.

Nonetheless, although stem and bark represented most of the tree biomass, the concentration of macronutrients in these components was lower (Table 4). Merino et al. (2005), Viera et al. (2011) and Salvador et al. (2016), studying forest essences, also reported that the leaves presented the highest levels of macronutrients, constituting an important return route of the mineral elements from the vegetation to the soil.

Furthermore, the order of distribution of nutrient contents found for most of the compartments of Pinus species $(\mathrm{N}>\mathrm{K}>\mathrm{Ca}>\mathrm{Mg}>\mathrm{P})$ (Table 4) is in accordance with that observed by Viera et al. (2013).

The highest concentrations of $\mathrm{P}$ and $\mathrm{Ca}$ observed in the leaves of $P$. caribaea in pure planting (Table 4) suggests a lower efficiency of use of these nutrients (EUN), considering that there was no significant variation in the amount of biomass produced by the species studied under both planting conditions (Table 3). According to Schumacher and Poggiani (1993), several factors can influence the distribution of nutrients in a plant, being among them the nutritional characteristics of each species, soil fertility levels, and forest age. However, variations in nutrient concentrations may be related not only to the intrinsic characteristics of each species of Pinus, but also to the stands composition (homogeneous or heterogeneous). According to Marschner (1997), the EUN can vary within a plant species depending on the genotype-environment interaction that conditions the nutrient absorption, translocation and conversion capacity in biomass.

Contrastively, the nutrient that suffered the greatest variation with the residues management (removal of stem with or without bark) was the Ca. Thus, it is justified by the fact that the bark presents higher amounts of this nutrient, since it is not very movable in the vegetal tissues and its concentration increases with plant age (Freitas et al., 2004). Coincidentally, Guimaraes et al. (2015) in plantings of Eucalyptus dunnii, and Freitas et al. (2004) in stands of Eucalyptus grandis, also verified that the $\mathrm{Ca}$ was the element that presented greater variation in the exportation when considering the harvest with or without bark.

In general, in management 2 (removal of stem with bark), the export percentages of each nutrient were higher than $40 \%$ (Table 5). Close results were observed by Santana et al. (2008) in eucalyptus plantations located in different sites in Brazil, which verified that more than $70 \%$ of the macronutrients $\mathrm{N}, \mathrm{P}, \mathrm{K}, \mathrm{Ca}$ and $\mathrm{Mg}$ were contained in leaves, branches and bark components.

The removal of the entire tree was the most important nutrient removal condition (Table 5), especially for $\mathrm{N}, \mathrm{P}$ and $\mathrm{K}$, possibly presenting future reflexes on the nutritional balance and maintenance of the productive capacity of the site. Additionally, according to Merino et al. (2005), the export of some nutrients, such as P and K, in forest plantations can equal or even exceed the available reserves in the soil, which may affect the supply of nutrients over time. This underscores the importance of management with conservation of all harvesting residues in the field for the sustainability of forest production and reduction of costs with fertilizers.

\section{CONCLUSIONS}

- In the tree biomass composition of Pinus plantations, the most representative compartments are wood and bark, while the needles have greater expression in the concentration of nutrients.

- For the three conditions of waste management, the elements that represent the highest risk for maintaining productivity are $\mathrm{Ca}$ and $\mathrm{Mg}$.

- Mixed planting is more likely to export $\mathrm{P}, \mathrm{K}$, and $\mathrm{Mg}$ in relation to pure planting.

- Removal of bark leads to too much nutrient removal, in some cases reaching $50 \%$ of the total biomass $(\mathrm{Ca}$, $\mathrm{Mg}$ and $\mathrm{N}$ in pure planting; $\mathrm{Ca}, \mathrm{Mg}$ and $\mathrm{K}$ in mixed planting).

- For both plantations, $64 \%$ of the nutrient set (N, P, K, Ca and Mg) are in other components of the tree aerial part and not in the wood, which shows that the maintenance of the needles, branches and bark in the field can contribute systematically to the nutritional sustainability of the site. 


\section{REFERENCES}

BELLOTE, A. F. J.; DEDECEK, R. A.; SILVA, H. D. Nutrientes minerais, biomassa e deposição de serapilheira em plantio de Eucalyptus com diferentes sistemas de manejo de resíduos florestais. Pesquisa Florestal Brasileira, n. 56, p. 31-41, 2008.

CALDEIRA, M. V. W.; OLIVEIRA GODINHO, T.; SAIDELLES, F. L. F.; VIERA, M.; SCHUMACHER, M. V.; CASTRO, K. C. Carbon and nutrients output by harvesting Acacia mearnsii De Wild to four years old at the central Depression, RS. Comunicata Scientiae, v. 5, n. 1, p. 68-74, 2014.

CORRÊA, R. S.; BELlOTE, A. F. J. Soil attributes and biomass yield from Pinus caribaea var. hondurensis. Cerne, v. 17, n. 2, p. 181-187, 2011.

EMPRESA BRASILEIRA DE PESQUISA AGROPECUÁRIA (EMBRAPA). Cultivo de Pinus. Sistemas de Produção. 2. ed. Versão Eletrônica, 2014. Disponível em: < https://bit.ly/2KQrrfT > Acesso em: 12 jul. 2018.

EMPRESA BRASILEIRA DE PESQUISA AGROPECUÁRIA (EMBRAPA). Manual de Métodos de Análise de Solo. 3. ed. Brasília, DF, 2017. 573 p.

FREITAS, R. et al. Biomassa e conteúdo de nutrientes em povoamento de Eucalyptus grandis W. Hill ex Maiden plantado em solo sujeito à arenização, no município de Alegrete-RS. Biomassa \& Energia, v. 1, n. 1, p. 93-104, 2004

GUIMARAES, C. C. et al. Biomass and nutrients of Eucalyptus dunnii Maiden stand in Pampa Gaúcho. Revista Árvore, v. 39, n. 5, p. 873-882, 2015.

INDÚSTRIA BRASILEIRA DE ÁRVORES (IBÁ). Relatório Ibá 2017. São Paulo: IBÁ, 2017. Disponível em: < http://iba.org/images/shared/Biblioteca/IBA_RelatorioAnual2017.pdf> Acesso em: 12 jul. 2018.

LIMA, M. C. D. et al. Biomass and carbon stock from Pinus caribaea var. hondurensis under homogenous stands in southwest Bahia, Brazil. Ciência Rural, v. 46, n. 6, p. 957-962, 2016.

MADEIRA, M.; FABIÃO, A.; PÁSCOA, F.; MAGALHÃES, M. D. C.; CAMEIRA, M. C.; RIBEIRO, C. Carbono e nutrientes na biomassa aérea arbórea, vegetação sob coberto e solo numa cronossequência de povoamentos de pinhal bravo. Revista Brasileira de Ciências Agrárias, v. 32, n. 2, p. 154-170, 2009.

MARSCHNER, H. Mineral nutrition of higher plants. 2. ed. San Diego: Academic Press, 1997. 889 p.

MERINO, A. et al. Nutrient exports under different harvesting regimes in fast-growing forest plantations in southern Europe. Forest Ecology and Management, v. 207, n. 3, p. 325-339, 2005.

PAES, F. A. Z. V. et al. Impacto do manejo dos resíduos da colheita, do preparo do solo e da adubação na produtividade de eucalipto. Revista Brasileira de Ciência do Solo, v. 37, n. 4, 2013.

PEDROSA, T. D. et al. Estimativa da biomassa em um plantio de Eucalyptus grandis na região CentroOeste. Scientia Plena, v. 9, n. 5, 2013.

SALVADOR, S. M. et al. Biomassa e estoque de nutrientes em plantios clonais de Eucalyptus saligna Smith. em diferentes idades. Scientia Forestalis, v. 44, n. 110, 2016.

SANTANA, R. C. et al. Alocação de nutrientes em plantios de eucalipto no Brasil. Revista Brasileira de Ciência do Solo, v. 32, 2008.

SCHUMACHER, M. V.; CALDEIRA, M. V. W. Estimativa da biomassa e do conteúdo de nutrientes de um povoamento de Eucalyptus globulus (Labillardière) sub-espécie maidenii. Ciência Florestal, v. 11, n. 1, p. 45-53, 2001.

SCHUMACHER, M. V.; POGGIANI, F. Produção de biomassa e remoção de nutrientes em povoamentos de Eucalyptus camaldulensis Dehnh, Eucalyptus grandis hill ex Maiden e Eucalyptus torelliana F. Muell, plantados em Anhembí, SP. Ciência Florestal, v. 3, n. 1, p. 21-34, 1993.

SCHUMACHER, M. V.; WITSCHORECK, R.; CALIL, F. N.; LOPES, V. G. Biomassa e nutrientes no corte raso de um povoamento de Pinus taeda L. de 27 anos de idade em Cambará do Sul - RS. Ciência Florestal, v. 23, n. 2, p. 321-332, 2013.

FLORESTA, Curitiba, PR, v. 49, n. 3, p. 571 - 578, jul/set 2019.

Gomes, V. S. et.al.

ISSN eletrônico 1982-4688

DOI: 10.5380/rf.v49 i3.60531 
SETTE JUNIOR, C. R.; NAKAJIMA, N. Y.; GEROMINI, M. P. Captura de carbono orgânico em povoamentos de Pinus taeda L. na região de Rio Negrinho, SC. Floresta, v. 36, n. 1, p. 33-44, 2006.

SIXEL, R. M. M. et al. Sustainability of wood productivity of Pinus taeda based on nutrient export and stocks in the biomass and in the soil. Revista Brasileira de Ciência do Solo, v. 39, n. 5, p. 1416-1427, 2015.

TEDESCO, M. J. et al. Análises de solo, plantas e outros materiais. Porto Alegre: UFRGS, 1995.

TUTUA, S. S. et al. Long-term impacts of harvest residue management on nutrition, growth and productivity of an exotic pine plantation of sub-tropical Autralia. Forest ecology and management, v. 256, n. 4, p. 741-748, 2008.

VIERA, M.; SCHUMACHER, M. V.; BONACINA, D. M. Biomassa e nutrientes removidos no primeiro desbaste de um povoamento de Pinus taeda L. em Cambará do Sul, RS. Revista Árvore, v. 35, n. 3, p. 371-379, 2011.

VIERA, M.; SCHUMACHER, M. V.; KLEINPAUL, I. S. Estoque de nutrientes em consórcios de Eucalyptus urograndis, Acacia mearnsii e Zea mays. Ciência Florestal, v. 23, n. 3, p. 317-327, 2013. 